\title{
NON-FINANCIAL REPORTING IN THE POSTAL SERVICES INDUSTRY
}

\author{
Danica Rajin ${ }^{1 *}$, \\ Marijana Petrović2, \\ Tijana Radojević 3
}

${ }^{1}$ FEFA,

Belgrade, Serbia

${ }^{2} \mathrm{ICT}$ College,

Belgrade, Serbia

${ }^{3}$ Singidunum University,

Belgrade, Serbia

\begin{abstract}
:
The aim of this paper is to analyze the role of the Post of Serbia as the leader in the field of postal, financial and information-communication services in the domestic market. The paper will provide an overview of company's goals to maintain competitiveness and market leadership position. The Post of Serbia needs to develop and liberalize in accordance with the EU policy of gradual and controlled liberalization. The harmonization of national legislative rules with the EU regulatory framework led to a sustained leadership position in the Serbian market, despite increasing legal and illegal competition. This tendency can be observed in their management reports, particularly in the reports related to the volume of services provided in the previous years. The paper includes data analysis of ten-year business, collected from reports of the Post of Serbia.
\end{abstract}

\section{Keywords:}

ostal services, reporting, harmonization of laws

\section{INTRODUCTION}

In the field of postal, financial and information-communication services, the Post of Serbia is the leader in the domestic market, where it develops and provides services that are of high quality and widely available. The vision of the company clearly emphasizes the tendency to maintain competitiveness and market leadership, which in recent times has been characterized by an increasing presence of competition and a growing change in the needs and wishes of service users. In addition to having to adapt to market demands, the Post of Serbia has to be developed and liberalized in accordance with the EU policy on gradual and controlled liberalization (Jovičić, 2015; EU passes liberalization of postal services, 2014). The harmonization of national legislative rules with the EU regulatory framework has led to the fact that the market is largely demonopolized in Serbia, with the exception of the segment of consignments of up to 100 grams and an even smaller segment where the Post of Serbia has exclusive right. According to the public company, there are currently 47 private registered operators in Serbia, and complete liberalization, i.e. the abolition of the exclusive right of the Post of Serbia is related to the end of pre-accession negotiations of Serbia with the European Union (Grgurović, Štrbac \& Popović, 2010). 


\section{BASIC CHARACTERISTICS OF POSTAL SERVICES}

The term "postal service" means the services of receiving the items at the counter or at the address of the user, their transportation, processing and delivery at the request of individuals or legal persons (Law on Postal Services, 2014). Postal services include letterhead, referral, package and special services, value added services, services on request and ex officio (Law on Postal Services, 2014). Post office performs postal services on the territory of the Republic of Serbia, which is internal postal traffic, as well as services in international postal services, where reception, transfer, processing and delivery of consignments that are heard for countries abroad or arrive from abroad are addressed in the Republic of Serbia (Customs law, 2017).

The public postal operator is obliged to provide universal postal service in the entire territory of the Republic of Serbia, which means that there is a set of basic postal services that must be continuously carried out within the prescribed quality, at affordable prices and equal conditions for all users on the territory of the Republic of Serbia. Therefore, there is no discrimination in the provision of certain postal services and all must be done in the same way, whether it is to serve users in the city or in the furthest place, in accordance with the Law and other regulations that regulate the performance of postal services.

Reserved postal services are services that the state guarantees to a postal service provider providing universal postal service as exclusive rights within a certain limit by weight and price, because often the provision of universal service is unprofitable outside large cities and this is one of the reasons why it is not done by anyone except Post (Rulebook on general conditions for the provision of postal services, 2015). The limit by weight and the price for reserved postal services is determined by the Republic Agency for Postal Services with the consent of the Government of the Republic of Serbia and it can not exceed $100 \mathrm{gr}$ and a triple amount of postage per letter of the first rate of weight and the fastest transfer rate (Rulebook on general conditions for the provision of postal services, 2015).

Unreserved postal services include postal services from the universal service domain that exceed the established limits by mass and prices for reserved services and all other postal services, including commercial services (express services, courier services and services with specific user requirements regarding the quality of postal services and mode of transmission).

The public postal operator is obliged to provide all residents of the Republic of Serbia with reserved and unreserved postal services from the domain of universal postal services, with the possibility of providing other postal services
(Strategy of development of postal services in Serbia for the period 2013-2016). There are 17 registered postal operators on the website of the Republic Agency for Electronic Communications and Postal Services (RATEL), while the search on the Internet reaches a figure of over 50 private operators that provide certain types of postal services. Other postal operators cannot provide reserved postal services, but may provide non-reserved postal services that are universal or outside of that domain.

\section{METHODOLOGY}

The paper encompasses the ten-year operation of the Post of Serbia in the field of provision of reserved, unreserved/universal postal services and services of commercial services for the period from 2007 to 2016 with the aim to analyze the movement of demand for these services by years and forecast trends in the current year and 2018. The data that provide information on the subject of the research are the official data of the public company Post of Serbia.

\section{RESULTS AND DISCUSSION}

The following table shows the total physical volume of provisioned, unreserved/universal postal services and commercial services provided for the period from 2007 to 2016.

\section{Selected statistical prediction methods}

The selected method of statistical prediction in this paper is a dynamic analysis method based on time series, linear trend method.

\section{Application of the linear trend method}

The evolution of the time series can be monitored using the linear trend method. The following tables give parameters for calculating the linear equation of the trend and the forecast of production in 2017 and 2018 for postal, IT and other services and financial operations. On that basis a graphic representation of their movement was made.

\section{Linear trend method applied to postal services}

The physical volume of completed postal services by years, shown in millions of statistical units (in this case in millions of services) is given in the following table. 


\begin{tabular}{|c|c|c|c|c|c|c|c|c|c|c|c|c|}
\hline & ํㅜㄹ & 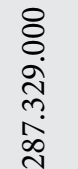 & $\begin{array}{l}8 \\
8 \\
\stackrel{0}{n} \\
\stackrel{+}{+} \\
\stackrel{+}{N}\end{array}$ & 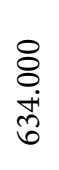 & $\begin{array}{l}\stackrel{8}{0} \\
\dot{+} \\
\infty \\
+ \\
+\end{array}$ & $\begin{array}{l}\text { ¿े } \\
\stackrel{0}{0} \\
\stackrel{n}{n}\end{array}$ & $\begin{array}{l}8 \\
0 \\
\stackrel{1}{0} \\
\alpha \\
\dot{J}\end{array}$ & 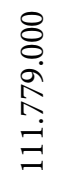 & 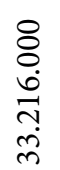 & 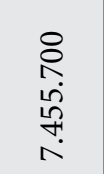 & $\begin{array}{l}8 \\
8 \\
\hat{0} \\
\stackrel{1}{0} \\
\text { î. }\end{array}$ & 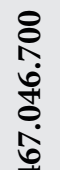 \\
\hline & $\stackrel{n}{\text { กิ }}$ & 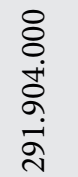 & 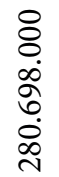 & 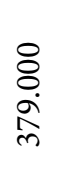 & $\begin{array}{l}8 \\
\varnothing \\
\infty \\
0 \\
\stackrel{0}{0} \\
\leftrightarrow\end{array}$ & 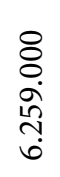 & 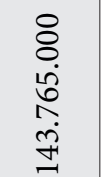 & \begin{tabular}{l}
8 \\
8 \\
$\infty$ \\
\multirow{+}{+}{} \\
$\stackrel{0}{0}$ \\
$\circ$
\end{tabular} & 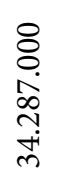 & $\begin{array}{l}8 \\
\infty \\
\infty \\
\infty \\
\dddot{1} \\
\end{array}$ & 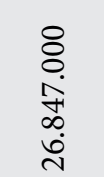 & 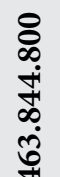 \\
\hline & $\underset{\sim}{\vec{~}}$ & $\begin{array}{l}8 \\
8 \\
0 \\
0 \\
0 \\
\stackrel{\text { iे }}{ }\end{array}$ & $\begin{array}{l}8 \\
0 \\
0 \\
0 \\
0 \\
\dot{0} \\
\infty \\
0\end{array}$ & $\begin{array}{l}\stackrel{8}{0} \\
\dot{0} \\
\infty \\
\text { r. }\end{array}$ & $\begin{array}{l}8 \\
8 \\
\dot{\theta} \\
\qquad \\
\ddot{+}\end{array}$ & $\begin{array}{l}8 \\
8 \\
\\
\hat{n} \\
\text { in }\end{array}$ & 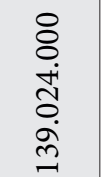 & $\begin{array}{l}8 \\
8 \\
\text { in } \\
\text { जn } \\
+ \\
0\end{array}$ & $\begin{array}{l}8 \\
8 \\
\circ \\
\circ \\
\stackrel{1}{1} \\
\dot{m}\end{array}$ & 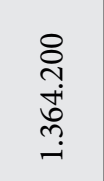 & 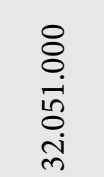 & $\begin{array}{l}\stackrel{8}{\circ} \\
\ddot{1} \\
\frac{1}{n} \\
10 \\
0\end{array}$ \\
\hline & $\stackrel{n}{\text { ¿ }}$ & 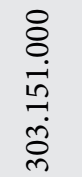 & 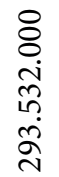 & $\begin{array}{l}8 \\
8 \\
\ddot{0} \\
\stackrel{+}{+}\end{array}$ & $\begin{array}{l}8 \\
\varnothing \\
\ddot{1} \\
\infty \\
\infty \\
\dot{n}\end{array}$ & $\begin{array}{l}8 \\
8 \\
\dot{8} \\
\text { iे } \\
i ்\end{array}$ & $\begin{array}{l}\stackrel{8}{0} \\
\ddot{g} \\
\stackrel{+}{\circ} \\
\text { m. }\end{array}$ & 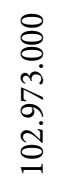 & $\begin{array}{l}8 \\
8 \\
0 \\
\stackrel{0}{0} \\
0 \\
0\end{array}$ & $\begin{array}{l}8 \\
10 \\
0 \\
0 \\
n\end{array}$ & $\begin{array}{l}8 \\
0 \\
+ \\
\infty \\
-1 \\
m\end{array}$ & 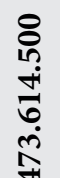 \\
\hline 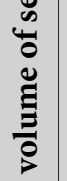 & ָี & $\begin{array}{l}\infty \\
0 \\
\infty \\
\infty \\
0 \\
0 \\
0 \\
0 \\
\infty\end{array}$ & 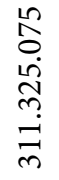 & $\begin{array}{l}\stackrel{H}{N} \\
\text { ñ } \\
\text { in } \\
\text { in }\end{array}$ & 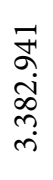 & $\begin{array}{l}\infty \\
0 \\
+1 \\
\stackrel{0}{0} \\
\infty \\
+ \\
+\end{array}$ & 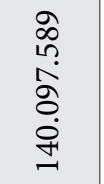 & \begin{tabular}{l}
$\hat{n}$ \\
\multirow{2}{*}{} \\
$\infty$ \\
$\infty$ \\
$\infty$ \\
$\dot{0}$ \\
0
\end{tabular} & 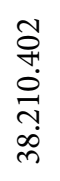 & $\begin{array}{l}\exists= \\
\stackrel{7}{a} \\
\infty\end{array}$ & $\begin{array}{l}\stackrel{2}{0} \\
\stackrel{+}{+} \\
\stackrel{+}{+} \\
\stackrel{n}{0}\end{array}$ & 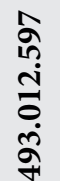 \\
\hline $\begin{array}{l}\frac{n}{2} \\
\frac{0}{2} \\
\frac{0}{0} \\
\tilde{0} \\
.0\end{array}$ & $\overline{\widetilde{N}}$ & \begin{tabular}{l}
$\hat{y}$ \\
\multirow{7}{N}{} \\
$\hat{N}$ \\
$\infty$ \\
0 \\
0 \\
0
\end{tabular} & 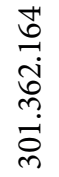 & $\begin{array}{l}\infty \\
\infty \\
+ \\
\text { fin } \\
\text { in }\end{array}$ & 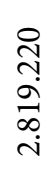 & 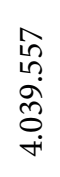 & 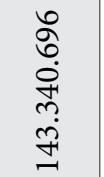 & 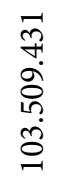 & \begin{tabular}{l}
$\qquad 0$ \\
$\stackrel{0}{0}$ \\
\hdashline \\
$\infty$ \\
$\infty$ \\
$\dot{m}$
\end{tabular} & $\begin{array}{l}\infty \\
\underset{\sim}{\not} \\
\underset{\sim}{\sim}\end{array}$ & 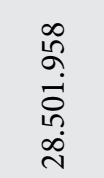 & 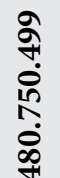 \\
\hline & 록 & 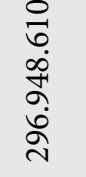 & 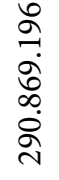 & $\begin{array}{l}\vec{\sigma} \\
\vec{\sigma} \\
\text { in }\end{array}$ & 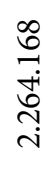 & 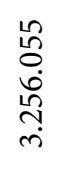 & 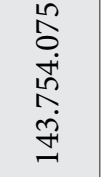 & $\begin{array}{l}8 \\
\infty \\
\ddot{8} \\
\stackrel{8}{0} \\
\dot{8}\end{array}$ & 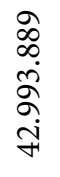 & 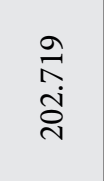 & 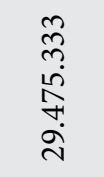 & 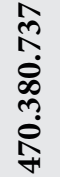 \\
\hline & ڤ્సે & 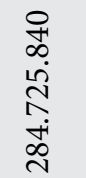 & 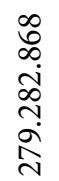 & $\begin{array}{l}\overrightarrow{\mathrm{J}} \\
\stackrel{\mathbb{8}}{0}\end{array}$ & 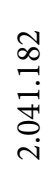 & 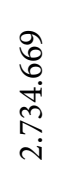 & 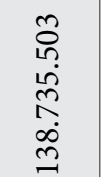 & 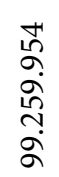 & 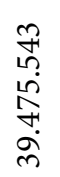 & $\begin{array}{l}n \\
\hat{n} \\
\text { ते } \\
\text { nె. }\end{array}$ & 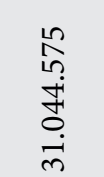 & $\begin{array}{l}m \\
1 n \\
\infty \\
\infty \\
\infty \\
1 \\
1\end{array}$ \\
\hline & ڤ్సి & 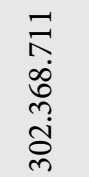 & 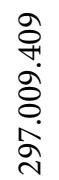 & 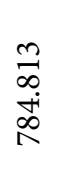 & 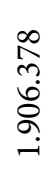 & $\begin{array}{l}\exists \\
\exists \\
0 \\
0 \\
0 \\
i\end{array}$ & 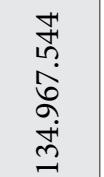 & 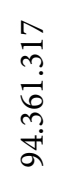 & 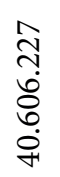 & 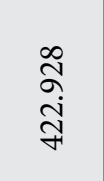 & 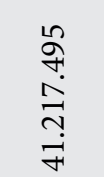 & 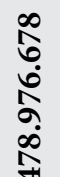 \\
\hline & ڤ్ & 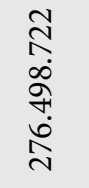 & 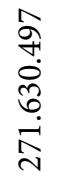 & 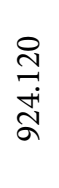 & 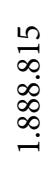 & 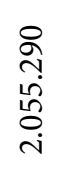 & 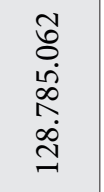 & 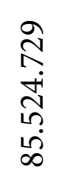 & 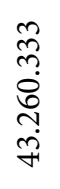 & 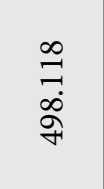 & 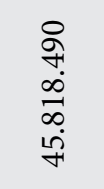 & 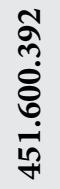 \\
\hline है & 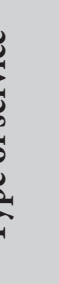 & 点 & & 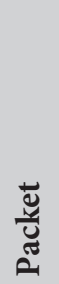 & 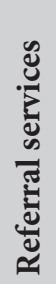 & 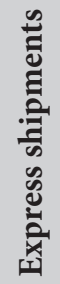 & 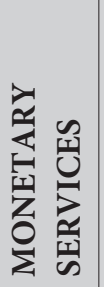 & 苞 & 总 & 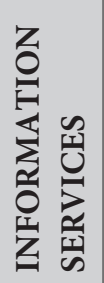 & 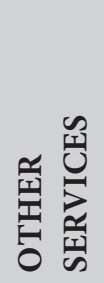 & 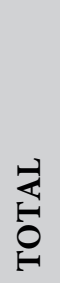 \\
\hline
\end{tabular}


Table 2. Linear trend method applied to postal services

\begin{tabular}{|c|c|c|c|c|c|}
\hline \multicolumn{6}{|c|}{ Postal services } \\
\hline Year & $\begin{array}{l}y_{t} \text { original data } \\
\text { (in millions of } \\
\text { statistical units) }\end{array}$ & $x_{i}$ & $y_{i} x_{i}$ & $x_{i}^{2}$ & $\hat{y}_{l}$ \\
\hline 2007 & 276.5 & -3.5 & -967.75 & 12.25 & 294.2074167 \\
\hline 2008 & 302.37 & -2.5 & -755.925 & 6.25 & 294.8587262 \\
\hline 2009 & 284.73 & -1.5 & -427.095 & 2.25 & 295.5100357 \\
\hline 2010 & 296.95 & -0.5 & -148.475 & 0.25 & 296.1613452 \\
\hline 2011 & 308.78 & 0 & 0 & 0 & 296.487 \\
\hline 2012 & 320.08 & 0 & 0 & 0 & 296.487 \\
\hline 2013 & 303.15 & 0.5 & 151.575 & 0.25 & 296.8126548 \\
\hline 2014 & 293.08 & 1.5 & 439.62 & 2.25 & 297.4639643 \\
\hline 2015 & 291.90 & 2.5 & 729.75 & 6.25 & 298.1152738 \\
\hline 2016 & 287.33 & 3.5 & 1005.655 & 12.25 & 298.7665833 \\
\hline Total & 2964.87 & 0 & 27.355 & 42 & 2964.87 \\
\hline
\end{tabular}

Source: Authors' calculation

According to the given table, we can define the following parameters:

$a=\frac{\sum y_{i}}{n}=\frac{2964,87}{10}=296,487$

$b=\frac{\sum y_{i} x_{i}}{\sum x_{i}^{2}}=\frac{27,355}{42}=0,651$

The equation of the linear trend is:

$\hat{y}_{l}=a+b \cdot x_{i}$

$\hat{y}_{l}=296,487+0,651 \cdot x_{i}$

The forecast for 2017 and 2018 is:

$\hat{y}_{2017}=296,487+0,651 \cdot 4,5=296,487+2,9295=299,4165$

$\hat{y}_{2018}=296,487+0,651 \cdot 5,5=296,487+3,5805=300,0675$

Using the linear trend method, there is a forecast that more postal services will be carried out in 2017 than in 2016, in the volume of more than 12.087 .500 services on average, while in 2018 a milder increase in demand for services is expected for 651.000 services compared to 2017.
Figure 1. Demand for postal services

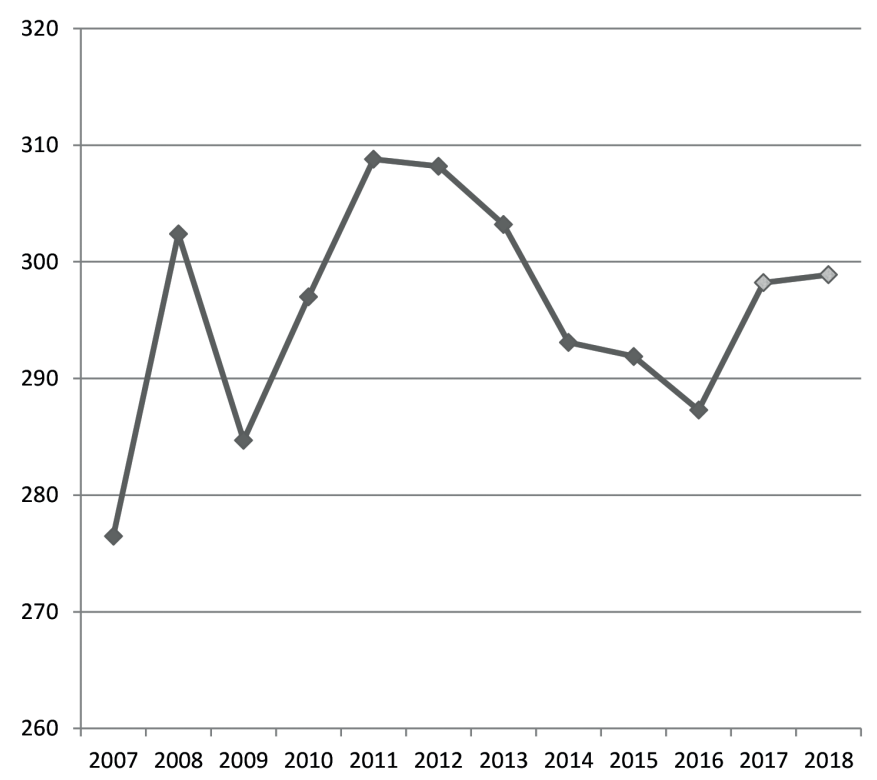

More detailed analysis of individual segments of postal services

Postal services can be divided into letterhead, packet, referral and post express services. Each category shows different oscillations in demand for services, so their deeper analysis leads to more detailed information in which area of postal services can an increase or decline in demand be expected in the future. 
Letterhead, packet and Post Express services include the receipt, transfer and delivery of mail to users, while re- ferral services involve the receipt, transfer and delivery of money in the territory of the Republic of Serbia or abroad.

Table 3. Linear trend method applied to letterhead services

\begin{tabular}{|c|c|c|c|c|c|}
\hline \multicolumn{6}{|c|}{ Letterhead services } \\
\hline Year & $\begin{array}{l}y_{t} \text { original data } \\
\text { (in millions of } \\
\text { statistical units) }\end{array}$ & $x_{i}$ & $y_{i} x_{i}$ & $x_{i}^{2}$ & $\hat{y}_{l}$ \\
\hline 2007 & 271.63 & -3.5 & -950.705 & 12.25 & 290.31775 \\
\hline 2008 & 297.01 & -2.5 & -742.525 & 6.25 & 289.74525 \\
\hline 2009 & 279.28 & -1.5 & -418.92 & 2.25 & 28917275 \\
\hline 2010 & 290.86 & -0.5 & -145.43 & 0.25 & 288.60025 \\
\hline 2011 & 301.36 & 0 & 0 & 0 & 288.314 \\
\hline 2012 & 311.33 & 0 & 0 & 0 & 288.314 \\
\hline 2013 & 293.53 & 0.5 & 146.765 & 0.25 & 288.02775 \\
\hline 2014 & 283.01 & 1.5 & 424.515 & 2.25 & 287.45525 \\
\hline 2015 & 280.7 & 2.5 & 701.75 & 6.25 & 286.88275 \\
\hline 2016 & 274.43 & 3.5 & 960.505 & 12.25 & 286.31025 \\
\hline Total & 2883.14 & 0 & -24.045 & 42 & 2883.14 \\
\hline
\end{tabular}

Source: Authors' calculation

According to the given table, we can define the following parameters:

$a=\frac{\sum y_{i}}{n}=\frac{2883,14}{10}=288,314$

$b=\frac{\sum y_{i} x_{i}}{\sum x_{i}^{2}}=\frac{-24,045}{42}=-0,5725$

The equation of the linear trend is:

$$
\begin{aligned}
& \hat{y}_{l}=a+b \cdot x_{i} \\
& \hat{y}_{l}=288,314-0,5725 \cdot x_{i}
\end{aligned}
$$

The forecast for 2017 and 2018 is:

$\hat{y}_{2017}=288,314-0,5725 \cdot 4,5=288,314-2,576=285,738$

$\hat{y}_{2018}=288,314-0,5725 \cdot 5,5=288,314-3,149=285,165$

According to the applied linear trend equation, we can conclude that in 2017, an average of 285.738 .000 searched services is expected, while in 2018, 285.165.000 is expected.

Packet services are services of receiving, transferring and the delivery of registered mailings from 2 to $31,5 \mathrm{~kg}$, which can be with or without marked value and can contain goods and other items that are allowed by law and regulations for transmission in internal or international postal traffic. 
Table 4. Linear trend method applied to packet services

\begin{tabular}{|c|c|c|c|c|c|}
\hline \multicolumn{6}{|c|}{ Packet services } \\
\hline Year & $\begin{array}{l}y_{t} \text { original data (in } \\
\text { millions of statisti- } \\
\text { cal units) }\end{array}$ & $x_{i}$ & $y_{i} x_{i}$ & $x_{i}^{2}$ & $\hat{y}_{l}$ \\
\hline 2007 & 0.924 & -3.5 & -3.234 & 12.25 & 0.795075 \\
\hline 2008 & 0.785 & -2.5 & -1.9625 & 6.25 & 0.7342536 \\
\hline 2009 & 0.667 & -1.5 & -1.0005 & 2.25 & 0.6734321 \\
\hline 2010 & 0.559 & -0.5 & -0.2795 & 0.25 & 0.6126107 \\
\hline 2011 & 0.554 & 0 & 0 & 0 & 0.5822 \\
\hline 2012 & 0.541 & 0 & 0 & 0 & 0.5822 \\
\hline 2013 & 0.406 & 0.5 & 0.203 & 0.25 & 0.5517893 \\
\hline 2014 & 0.38 & 1.5 & 0.57 & 2.25 & 0.4909679 \\
\hline 2015 & 0.372 & 2.5 & 0.93 & 6.25 & 0.4301464 \\
\hline 2016 & 0.634 & 3.5 & 2.219 & 12.25 & 0.369325 \\
\hline Total & 5.822 & 0 & -2.5545 & 42 & 5.822 \\
\hline
\end{tabular}

Source: Authors' calculation

According to the given table, we can define the following parameters:

$a=\frac{\sum y_{i}}{n}=\frac{5,822}{10}=0,5822$

$b=\frac{\sum y_{i} x_{i}}{\sum x_{i}^{2}}=\frac{-2,5545}{42}=-0,060821$

The equation of the linear trend is:

$\hat{y}_{l}=a+b \cdot x_{i}$

$\hat{y}_{1}=0,5822-0,060821 \cdot x_{i}$

The forecast for 2017 and 2018 is:

$$
\begin{aligned}
& \hat{y}_{2017}=0,5822-0,060821 \cdot 4,5=0,5822-0,274=0,3082 \\
& \hat{y}_{2018}=0,5822-0,060821 \cdot 5,5=0,5822-0,335=0,2472
\end{aligned}
$$

Packet services had a steady decline in demand by 2016, when demand jumped by $59 \%$. However, the linear trend equation predicts a decline in demand in 2017 to 308.200 services on average, while 2018 predicts an additional decline in demand for 61.000 services.

In the territory of the Republic of Serbia, the referral services include the receipt, transfer and delivery of money through the Postal or PostNet referral. Money can be delivered at the address of the user or at the Post office. Intra-passenger transport services include the same services on the territory of a foreign country, via the Western Union system or via the International Postal Order which can be sent to certain countries ${ }^{1}$.

1 The countries to which money can be sent through the International Referral List are: France, Russia, Ukraine, Belarus, Montenegro, Croatia, Bosnia and Herzegovina (The Republic of Srpska and the Federation of Bosnia and Herzegovina) and Qatar 
Table 5. Linear trend method applied to referral services

\begin{tabular}{|c|c|c|c|c|c|}
\hline \multicolumn{6}{|c|}{ Referral services } \\
\hline Year & $\begin{array}{l}y_{t} \text { original data } \\
\text { (in millions of } \\
\text { statistical units) }\end{array}$ & $x_{i}$ & $y_{i} x_{i}$ & $x_{i}^{2}$ & $\hat{y}_{l}$ \\
\hline 2007 & 1.89 & -3.5 & -6.615 & 12.25 & 1.4148333 \\
\hline 2008 & 1.91 & -2.5 & -4.775 & 6.25 & 1.9174524 \\
\hline 2009 & 2.04 & -1.5 & -3.06 & 2.25 & 2.4200714 \\
\hline 2010 & 2.26 & -0.5 & -1.13 & 0.25 & 2.9226905 \\
\hline 2011 & 2.82 & 0 & 0 & 0 & 3.174 \\
\hline 2012 & 3.38 & 0 & 0 & 0 & 3.174 \\
\hline 2013 & 3.82 & 0.5 & 1.91 & 0.25 & 3.4253095 \\
\hline 2014 & 4.16 & 1.5 & 6.24 & 2.25 & 3.9279286 \\
\hline 2015 & 4.57 & 2.5 & 11.425 & 6.25 & 4.4305476 \\
\hline 2016 & 4.89 & 3.5 & 17.115 & 12.25 & 4.9331667 \\
\hline Total & 31.74 & 0 & 21.11 & 42 & 31.74 \\
\hline
\end{tabular}

Source: Authors' calculation

According to the given table, we can define the following parameters:

$a=\frac{\sum y_{i}}{n}=\frac{31,74}{10}=3,174$

$b=\frac{\sum y_{i} x_{i}}{\sum x_{i}^{2}}=\frac{21,11}{42}=0,5026$

The equation of the linear trend is:

$\hat{y}_{l}=a+b \cdot x_{i}$

$\hat{y}_{1}=3,174+0,5026 \cdot x_{i}$

The forecast for 2017 and 2018 is:

$\hat{y}_{2017}=3,174+0,5026 \cdot 4,5=3,174+2,26=5,434$

$\hat{y}_{2018}=3,174+0,5026 \cdot 5,5=3,174+2,76=5,934$
Customer referral services show a constant increase in demand in the ten-year report, so it is expected in the upcoming period. For 2017, an increase in the volume on average is expected for 540.000 services more on this basis, while 2018 foresees 500.000 services provided more than in 2017.

Post Express Shipment is the fastest transfer service for shipments. For 108 cities in Serbia, there is a possibility that in the territory of the same city, the shipment is delivered to the recipient within a few hours. The second option available in 47 cities in Serbia is to deliver the shipment in the same day to the recipient in another city from 16 to $20 \mathrm{~h}$. The third possibility is that the shipment is handed over to one of over 800 available post offices and it will be delivered to any city next day by 12 or $19 \mathrm{~h}$, by the choice of the sender. 
Table 6. Linear trend method applied to express shipments

\begin{tabular}{|c|c|c|c|c|c|}
\hline \multicolumn{6}{|c|}{ Express shipments } \\
\hline Year & $\begin{array}{l}y_{t} \text { original data } \\
\text { (in millions of } \\
\text { statistical units) }\end{array}$ & $x_{i}$ & $y_{i} x_{i}$ & $x_{i}^{2}$ & $\hat{y}_{l}$ \\
\hline 2007 & 2.06 & -3.5 & -7.21 & 12.25 & 1.6778333 \\
\hline 2008 & 2.67 & -2.5 & -6.675 & 6.25 & 2.4590238 \\
\hline 2009 & 2.73 & -1.5 & -4.095 & 2.25 & 3.2402143 \\
\hline 2010 & 3.26 & -0.5 & -1.63 & 0.25 & 4.0214048 \\
\hline 2011 & 4.04 & 0 & 0 & 0 & 4.412 \\
\hline 2012 & 4.82 & 0 & 0 & 0 & 4.412 \\
\hline 2013 & 5.39 & 0.5 & 2.695 & 0.25 & 4.8025952 \\
\hline 2014 & 5.52 & 1.5 & 8.28 & 2.25 & 5.5827857 \\
\hline 2015 & 6.26 & 2.5 & 15.65 & 6.25 & 6.3649762 \\
\hline 2016 & 7.37 & 3.5 & 25.795 & 12.25 & 7.1461667 \\
\hline Total & 44.12 & 0 & 32.81 & 42 & 44.12 \\
\hline
\end{tabular}

Source: Authors' calculation

According to the given table, we can define the following parameters:

$a=\frac{\sum y_{i}}{n}=\frac{44,12}{10}=4,412$

$b=\frac{\sum y_{i} x_{i}}{\sum x_{i}^{2}}=\frac{32,81}{42}=0,7811905$

The equation of the linear trend is:

$\hat{y}_{l}=a+b \cdot x_{i}$

$\hat{y}_{l}=4,412+0,78131 \cdot x_{i}$

The forecast for 2017 and 2018 is:

$\hat{y}_{2017}=4,412+0,7811905 \cdot 4,5=4,412+3,51536=7,92736$

$\hat{y}_{2018}=4,412+0,7811905 \cdot 5,5=4,412+4,29655=8,70855$
The demand for Post Express shipments shows constant growth, so it is expected that in 2017 it will bring a higher demand in the volume of 7.927 .360 services requested on average, while in 2018 an even larger increase in the amount of 8.708 .550 services is expected.

Linear trend method applied to monetary services

Monetary services include payment services, which includes paying in and paying out of money from the accounts of individuals and legal persons on any basis (Law on Payment Transactions, 2014). The following table provides the original payment information data expressed in millions of services provided by years. 
Table 7. Linear trend method applied to monetary services

\begin{tabular}{|c|c|c|c|c|c|}
\hline \multicolumn{6}{|c|}{ Monetary services } \\
\hline Year & $\begin{array}{l}y_{t} \text { original data } \\
\text { (in millions of } \\
\text { statistical units) }\end{array}$ & $x_{i}$ & $y_{i} x_{i}$ & $x_{i}^{2}$ & $\hat{y}_{l}$ \\
\hline 2007 & 128.79 & -3.5 & -450.765 & 12.25 & 133.1158333 \\
\hline 2008 & 134.97 & -2.5 & -337.425 & 6.25 & 134.9455952 \\
\hline 2009 & 138.74 & -1.5 & -208.11 & 2.25 & 136.7753571 \\
\hline 2010 & 143.75 & -0.5 & -71.875 & 0.25 & 138.605119 \\
\hline 2011 & 143.34 & 0 & 0 & 0 & 139.52 \\
\hline 2012 & 140.10 & 0 & 0 & 0 & 139.52 \\
\hline 2013 & 139.15 & 0.5 & 69.575 & 0.25 & 140.434881 \\
\hline 2014 & 139.02 & 1.5 & 208.53 & 2.25 & 142.2646429 \\
\hline 2015 & 143.77 & 2.5 & 359.425 & 6.25 & 144.0944048 \\
\hline 2016 & 145.00 & 3.5 & 507.5 & 12.25 & 145.9241667 \\
\hline Total & 1396.36 & 0 & 76.855 & 42 & 1396.36 \\
\hline
\end{tabular}

Source: Authors' calculation

According to the given table, we can define the following parameters:

$a=\frac{\sum y_{i}}{n}=\frac{1396,63}{10}=139,663$

$b=\frac{\sum y_{i} x_{i}}{\sum x_{i}^{2}}=\frac{76,855}{42}=1,829881$

The equation of the linear trend is:

$\hat{y}_{l}=a+b \cdot x_{i}$

$\hat{y}_{l}=139,663+1,829881 \cdot x_{i}$

The forecast for 2017 and 2018 is:

$\hat{y}_{2017}=139,663+1,829881 \cdot 4,5=139,663+8,234=147,897$

$\hat{y}_{2018}=139,663+1,829881 \cdot 5,5=139,663+10,064=149,727$

In 2017 and 2018, an increase in demand for money services can be expected, by approximately 2.789 .000 services more in 2017 than in 2016, as well as the expected increase in 2018, which is estimated at 1.830 .000 more in comparison to the previous year.
Figure 2. Demand for monetary services

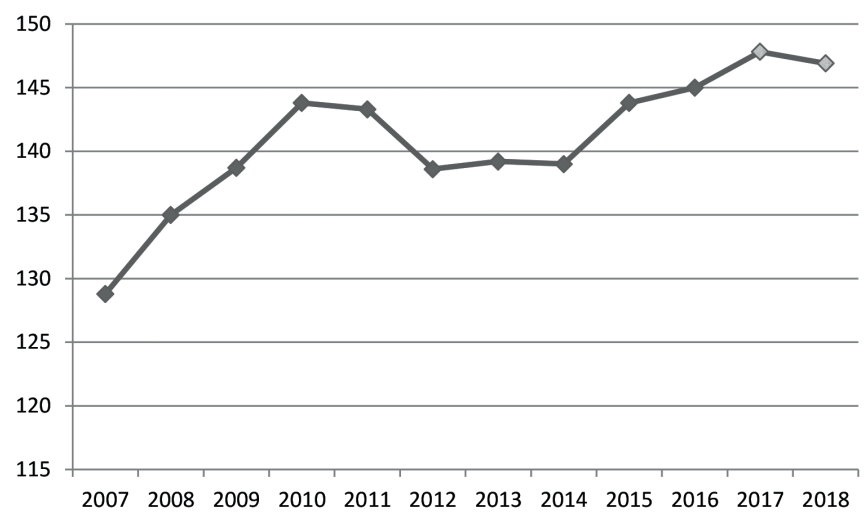

Linear trend method applied to information services

The information services of Post are: CEPP - Center for Electronic Business Post, e-Government and Post Certification Authority, GIS services (geographic information system), Post NET, distributed printing and packaging of documents and highly sophisticated IT projects, which include: multiservice corporate information and communication network PostNET, Integrated Enterprise Resource Management Information System (ERP) - PostSAP and Post Technological Information System - PostTIS. 
Table 8. Linear trend method applied to information services

\begin{tabular}{|c|c|c|c|c|c|}
\hline \multicolumn{6}{|c|}{ Information services } \\
\hline Year & $\begin{array}{c}y_{t} \text { original data } \\
\text { (in millions of sta- } \\
\text { tistical units) }\end{array}$ & $x_{i}$ & $y_{i} x_{i}$ & $x_{i}^{2}$ & $\hat{y}_{l}$ \\
\hline 2007 & 498.12 & -3.5 & -1743.42 & 12.25 & -1148.237917 \\
\hline 2008 & 422.93 & -2.5 & -1057.325 & 6.25 & -478.5356548 \\
\hline 2009 & 332.60 & -1.5 & -498.9 & 2.25 & 191.1666071 \\
\hline 2010 & 202.72 & -0.5 & -101.36 & 0.25 & 860.868869 \\
\hline 2011 & 132.42 & 0 & 0 & 0 & 1195.72 \\
\hline 2012 & 89.21 & 0 & 0 & 0 & 1195.72 \\
\hline 2013 & 130.50 & 0.5 & 65.25 & 0.25 & 1530.571131 \\
\hline 2014 & 1364.20 & 1.5 & 2046.3 & 2.25 & 2200.273393 \\
\hline 2015 & 1328.80 & 2.5 & 3322 & 6.25 & 2869.975655 \\
\hline 2016 & 7455.70 & 3.5 & 26094.95 & 12.25 & 3539.677917 \\
\hline Total & 11957.2 & 0 & 28127.495 & 42 & 11957.2 \\
\hline
\end{tabular}

Source: Authors' calculation

According to the given table, we can define the following parameters:

$a=\frac{\sum y_{i}}{n}=\frac{11957,2}{10}=1195,72$

$b=\frac{\sum y_{i} x_{i}}{\sum x_{i}^{2}}=\frac{28127,495}{42}=669,70226$

The equation of the linear trend is:

$\hat{y}_{l}=a+b \cdot x_{i}$

$\hat{y}_{l}=1195,72+6261,48 \cdot x_{i}$

The forecast for 2017 and 2018 is:

$\hat{y}_{2017}=1195,72+669,70226 \cdot 4,5=1195,72+3013,66=4209,38$

$\hat{y}_{2018}=1195,72+669,70226 \cdot 5,5=1195,72+3683,36=4843,08$
In 2016, Post had a very large increase in the scope of IT services, from approximately 1.328 .800 to as many as 74.557.000 services. The forecasts for 2017 are 4.209 .380 of the requested services, while the revenue which on average amounts to 4.843 .080 services is expected in 2018 .

Figure 3. Demand for information services

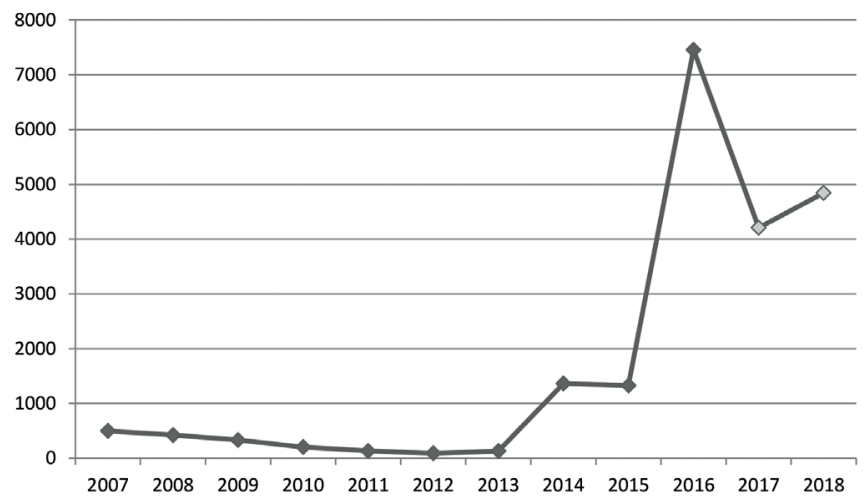

Linear trend method applied to other services

Other post services include: sale of free shares, telegraph services, sales, mediation booths, logistic services, packing services, etc. 
Table 9. Linear trend method applied to other services

\begin{tabular}{|c|c|c|c|c|c|}
\hline \multicolumn{6}{|c|}{ Other services } \\
\hline Year & $\begin{array}{l}y_{t} \text { original data } \\
\text { (in millions of } \\
\text { statistical units) }\end{array}$ & $x_{i}$ & $y_{i} x_{i}$ & $x_{i}^{2}$ & $\hat{y}_{l}$ \\
\hline 2007 & 45.82 & -3.5 & -160.37 & 12.25 & 40.82308333 \\
\hline 2008 & 41.22 & -2.5 & -103.05 & 6.25 & 38.47820238 \\
\hline 2009 & 31.04 & -1.5 & -46.56 & 2.25 & 36.13332143 \\
\hline 2010 & 29.48 & -0.5 & -14.74 & 0.25 & 33.78844048 \\
\hline 2011 & 28.50 & 0 & 0 & 0 & 32.616 \\
\hline 2012 & 32.75 & 0 & 0 & 0 & 32.616 \\
\hline 2013 & 31.18 & 0.5 & 15.59 & 0.25 & 31.44355952 \\
\hline 2014 & 32.05 & 1.5 & 48.075 & 2.25 & 29.09867857 \\
\hline 2015 & 26.85 & 2.5 & 67.125 & 6.25 & 26.75379762 \\
\hline 2016 & 27.27 & 3.5 & 95.445 & 12.25 & 24.40891667 \\
\hline Total & 326.16 & 0 & -98.485 & 42 & 326.16 \\
\hline
\end{tabular}

Source: Authors' calculation

According to the given table, we can define the following parameters:

$a=\frac{\sum y_{i}}{n}=\frac{326,16}{10}=32,616$

$b=\frac{\sum y_{i} x_{i}}{\sum x_{i}^{2}}=\frac{-98,485}{42}=-2,3449$

The equation of the linear trend is:

$\hat{y}_{l}=a+b \cdot x_{i}$

$\hat{y}_{l}=32,616+(-2,3449) \cdot x_{i}=32,39-2,3449 \cdot x_{i}$
The forecast for 2017 and 2018 is:

$\hat{y}_{2017}=32,616-2,3449 \cdot 4,5=32,616-10,551=22,064$

$\hat{y}_{2018}=32,616-2,3449 \cdot 5,5=32,616-12,897=19,719$

In the area of other services, there is a decreasing trend in value, so in 2017 there is a lower volume of required services in the amount of 22.064 .000 services on average, and in 2018 an additional drop in value is anticipated to 19.719.000 provided services.

Linear trend method applied to all services provided by Post

The table of original data showing the entire operation of the Post of Serbia at the ten-year level is given below. 
Table 10. Linear trend method applied to all services provided by Post

\begin{tabular}{|c|c|c|c|c|c|}
\hline \multicolumn{6}{|c|}{ All services } \\
\hline Year & $\begin{array}{l}y_{t} \text { original data } \\
\text { (in millions of } \\
\text { statistical units) }\end{array}$ & $x_{i}$ & $y_{i} x_{i}$ & $x_{i}^{2}$ & $\hat{y}_{l}$ \\
\hline 2007 & 451.60 & -3.5 & -1580.6 & 12.25 & 452.7310833 \\
\hline 2008 & 478.98 & -2.5 & -1197.45 & 6.25 & 459.1290595 \\
\hline 2009 & 454.84 & -1.5 & -682.26 & 2.25 & 465.5270357 \\
\hline 2010 & 470.38 & -0.5 & -235.19 & 0.25 & 471.9250119 \\
\hline 2011 & 480.75 & 0 & 0 & 0 & 475.124 \\
\hline 2012 & 477.56 & 0 & 0 & 0 & 475.124 \\
\hline 2013 & 473.62 & 0.5 & 236.81 & 0.25 & 478.3229881 \\
\hline 2014 & 465.52 & 1.5 & 698.28 & 2.25 & 484.7209643 \\
\hline 2015 & 463.84 & 2.5 & 1159.6 & 6.25 & 491.1189405 \\
\hline 2016 & 534.15 & 3.5 & 1869.525 & 12.25 & 497.5169167 \\
\hline Total & 4751.24 & 0 & 268.715 & 42 & 4751.24 \\
\hline
\end{tabular}

Source: Authors' calculation

According to the given table, we can define the following parameters:

$a=\frac{\sum y_{i}}{n}=\frac{4.751,24}{10}=475,124$

$b=\frac{\sum y_{i} x_{i}}{\sum x_{i}^{2}}=\frac{268,715}{42}=6,3979$

The equation of the linear trend is:

$$
\begin{aligned}
& \hat{y}_{l}=a+b \cdot x_{i} \\
& \hat{y}_{l}=475,124+6,3979 \cdot x_{i}
\end{aligned}
$$

The forecast for 2017 and 2018 is:

$$
\hat{y}_{2017}=475,124+6,3979 \cdot 4,5=475,124+28,7905=503,9145
$$

$\hat{y}_{2018}=475,124+6,3979 \cdot 5,5=475,124+35,1885=510,9125$

In 2017 it can be expected that the scope of the services provided by Post will amount to 503.914.500 services, while the increase in 2018 is estimated at 510.912 .500 services on average.
According to the linear trend, demand for all services provided by Post shows the absolute growth of the phenomenon, but this data should be considered cautiously and assuming that in 2017 and 2018, the conditions will be about the same as they were in the period when the trend was determined.

\section{CONCLUSION}

The linear trend method suggests that in the segment of letterhead services an increase in demand by $4,2 \%$ in 2017 and $0,22 \%$ in 2018 can be expected. In the monetary service segment, growth in demand for payment services can be expected to increase by $2 \%$ in 2017 and 1,24\% in 2018. Information services that in 2016 had an increase in demand by $561,1 \%$ compared to 2015 , according to the linear trend method will amount to 4.209 .380 requested services in 2017 and 4.843 .080 services in 2018. In the segment of other services, a decrease in demand is expected by $19,1 \%$ in 2017 compared to the previous year, and $10,6 \%$ in 2018 . The scope of all services provided by Post is expected to increase by $7,9 \%$ in 2017 and $1,4 \%$ in 2018 , provided the conditions remain similar to those that applied in the period from 2007 to 2016. It can be concluded that, in accordance with the applied methods, Post will have an increased demand for services in the coming years. 
In accordance with the business strategy of the Company, Post plans investments in the improvement and development of production potential, in order to realize the projected business activities and financial indicators for the current and the next year. By completing the construction of regional postal and logistics centers (Belgrade, Nis, Novi Sad), Post of Serbia has provided a basic requirement for the development of logistical services for storing and transporting goods for a larger number of potential users, thus generating new flows of transport of factory units, postal items and placement of services on the logistics market.

\section{LITERATURE}

Customs law, RS Official Gazette, No.18/2010, 111/2012, 29/2015, 108/2016 and 113/2017 - other law, Retrieved from http://www.carina.rs/lat/Zakoni/POSTA\%20lat. pdf

EU passes liberalization of postal services (2014). Retrieved from http://eupregovori.bos.rs/arhiva-vesti/291/2014/03/05/ poglavlje-3_-eu-donosi-liberalizaciju-postanskih-usluga. html

Grgurović, B., Štrbac, S \& Popović, M. (2010). Positioning in the market of commercial services the postal activities, International Scientific Conference MANAGEMENT 2010, Krusevac, Serbia, 17-18 March, 2010, Retrieved from http://www.meste.org/konf/Arhiva/Man_2010/ pdf/5_TehnologijeIAlatiMenadzmenta/GrgurovicStrbacPopovic.pdf

Jovičić, O. (2015). The role of regulation in the upcoming postal industry reform, XXXIII Symposium on new technologies in postal and telecommunication traffic - PosTel 2015, Belgrade, 1. i 2. december 2015. Retrieved from http://postel.sf.bg.ac.rs/simpozijumi/POSTEL2015/RADOVI\%20PDF/Postanski\%20saobracaj,\%20mreze\%20 i\%20servisi/1.\%20Jovicic.pdf
Law on Payment Transactions, RS Official Gazette, No. 5/2003, 43/2004, 62/2006, 111/2009 - other law, 31/2011 and 139/2014 - other law. Retrieved from http://paragraf.rs/propisi/zakon_o_platnom_prometu.html

Law on Postal Services, RS Official Gazette, No. 18/2005, 30 /2010 and $62 / 2014$, Retrieved from http://www.posta.rs/dokumenta/lat/o-nama/zakon-o-postanskim-uslugama.pdf

PE Post of Serbia (2013), Business report of the PE Post of Serbia, Belgrade, Retrieved from http://www.posta.rs/ dokumenta/lat/o-nama/program-poslovanja/programposlovanja-jp-ptt-saobracaja-srbija-2013.pdf

PE Post of Serbia (2014), Business report of the PE Post of Serbia, Belgrade, Retrieved from http://www.posta.rs/ dokumenta/lat/o-nama/program-poslovanja/programposlovanja-jp-posta-srbije-2014.pdf

PE Post of Serbia (2015), Business report of the PE Post of Serbia, Belgrade, Retrieved from http://www.posta.rs/ struktura/lat/o-nama/program-poslovanja/programposlovanja-2015.asp

PE Post of Serbia (2016), Business report of the PE Post of Serbia, Belgrade, Retrieved from http://www.posta.rs/ dokumenta/lat/o-nama/program-poslovanja/programposlovanja-jp-posta-srbije-za-2016.pdf

PE Post of Serbia (2017), Business report of the PE Post of Serbia, Belgrade, Retrieved from http://www.posta.rs/ dokumenta/lat/o-nama/program-poslovanja/Programposlovanja-JP-Posta-Srbije-za-2017.pdf

Rulebook on general conditions for the provision of postal services, RS Official Gazette, No. 24/2010, 58/2010, 2/2011, 13/2011, 65/2011, 93/2013 i 97/2015) Retrieved from http://www.posta.rs/dokumenta/lat/o-nama/pravilnici/ pravilnik-o-opstim-uslovima-za-obavljanje-postanskihusluga.pdf

Strategy of development of postal services in Serbia for the period 2013-2016, Retrieved from http://aler.rs/files/ STRATEGIJA_razvoja_postanskih_usluga_u_Srbiji_za_ period_2013_2016_godine_Sl_gl_RS_br_43_2013.pdf 